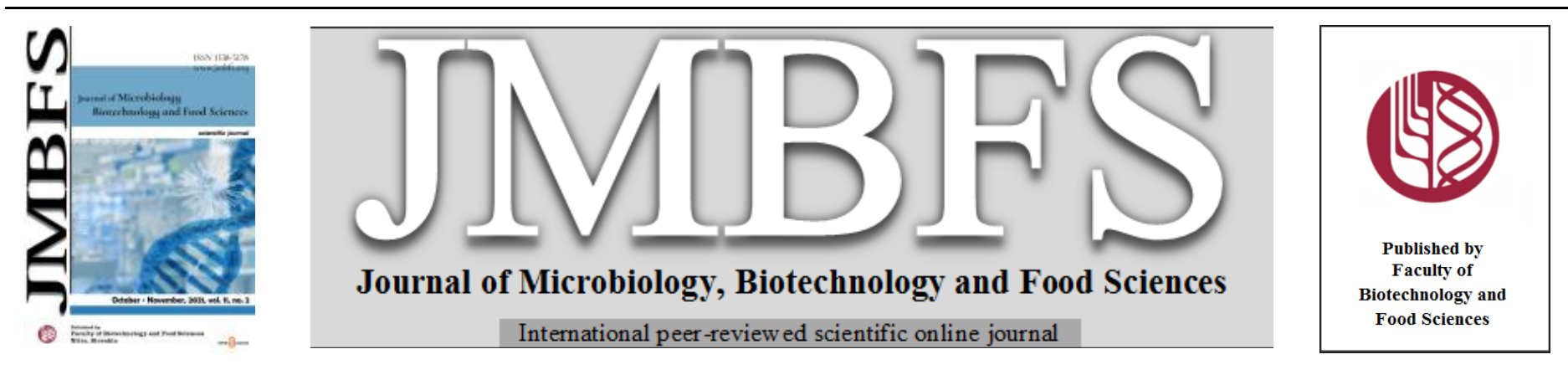

\title{
ANATOMICAL STUDIES ON THE ASSOCIATION OF ENDOPHYTIC FUNGI AND THEIR ISOLATION FROM ALANGIUM SALVIIFOLIUM (L.f.) Wangerin
}

\author{
S. Bavya $*^{l}$, S. Sahaya Sathish ${ }^{l}$, S. Dominic Rajkumar ${ }^{2}$, P. Vijayakanth ${ }^{3}$, V. Thangarajan ${ }^{l}$ and R. Kavitha ${ }^{l}$ \\ Address(es): \\ ${ }^{1}$ Department of Botany, St. Joseph's College, Tiruchirappalli - 620 002, Affiliated to Bharathidasan University, Tamilnadu, India. \\ ${ }^{2}$ Department of Botany, St. Andrew's College, Gorakhpur - 273 001, Uttar Pradesh, India. \\ ${ }^{3}$ Department of Botany, Aringar Anna College of Arts and science, Krishnagiri-635 001, Tamilnadu, India.
}

*Corresponding author: bavyagayathri@gmail.com

https://doi.org/10.15414/jmbfs.3497

ARTICLE INFO

Received 23. 7. 2020

Revised 11. 5. 2021

Accepted 18. 5. 2021

Published 1. 10. 2021

Regular article

OPEN $\partial_{\text {ACCESS }}$

\begin{abstract}
The present research was carried out to determine the anatomical features of leaves of Alangium salviifolium and their endophytic fungal association. Alangium salviifolium is an important medicinal plant with various activities reported. It is suggested that the medicinal property of the plant is either because of their endophytes or the endophytes inherit the medicinal properties from their host plant. Hence the detailed study of plant- microbe interaction is important. The anatomical features revealed the fungal mycelium in the ground cells of the abaxial midrib, the adaxial segment of xylem in the midrib. In the T.S of lamina, fungal hyphae are seen in the epidermis and also in the mesophyll tissue beneath the epidermal layer. Three endophytic fungi namely Aspergillus niger, Diaporthe longicolla and Schizophyllum commune were isolated and characterized using their ITS region.
\end{abstract}

Keywords: Endophytic fungi, Alangium salviifolium, light microscopy, molecular characterization

\section{INTRODUCTION}

Endophytes live inside the tissues of all plants without any sign of diseases(Petrini, 1991). Endophytes confer greater resistance to host against biotic and abiotic stresses, protects the plant against phytopathogens and produce chemical metabolites similar to that of the host (Bayat et al., 2009; Gundel et al., 2010). Endophytic fungi mainly include Ascomycota, Basidiomycota and Zygomycota(Tao et al., 2013). Microbes are the source of innumerable enzymes and secondary metabolites which have many applications in the biotechnology arena(Strobel \& Daisy 2003).

The presence of fungi inside the living leaves is detected mostly by culturedependent methods. Endophytic fungal hyphae present within the plant tissues are examined directly under light or electron microscope in the direct observation method. By this method even unculturable fungi can also be detected(Deckert $\boldsymbol{e t}$ al., 2001; Lucero et al., 2011). Direct observation using anatomical studies for the presence of fungal hyphae inside the leaves have been reported less(Deckert et al., 2001). Hence the current study was developed to locate the endophytic fungi inside the tissues of leaf and to isolate them. The plant chosen is an ethno medicinally important one, Alangium salviifolium. Each and every part of this plant is used in Siddha and Ayurveda. The plant belongs to the family Alangiaceae. The common name is sage leaved Alangium. It is a thorny tree and grows up to a height of $5-10 \mathrm{~m}$. It has antidiabetic(Kumar et al., 2011; Hepsy Kalrani D et a.,l 2012), antiulcer (Sreekanth et al., 2011), anti-arthritis(Jubie et al., 2008), anticancer(Zahan $\mathrm{R}$ et al., 2011), anti-inflammatory (Ahad et al., 2012) properties and so on.

\section{MATERIALS AND METHODS}

\section{Collection of specimens}

The plant material was collected from the Mambakkam forest area, Chennai. The fresh and healthy leaves of the plant were processed in the laboratory after collection. The collected plant was identified as Alangium salviifolium by Dr. P. Jayaraman, PARC, Tambaram (Voucher NO. PARC/2019/4044).

The required leaf samples were cut and fixed in FAA (Formalin-5ml + Acetic acid- $5 \mathrm{ml}+70 \%$ Ethyl alcohol-90ml). After 24hrs, graded series of tertiary Butyl alcohol was used for dehydration of specimens as given by Sass, 1940. Paraffin was infiltrated gradually until saturation. The specimens were cast into paraffin blocks.

\section{Sectioning}

The paraffin embedded specimens were sectioned (10-12 $\mu \mathrm{m}$ thickness) using Rotary Microtome. Dewaxing of the sections was by the customary procedure (Johansen, 1940). The sections were stained with toluidine blue, a polychromatic stain, as per the method published by O'Brieu et al., (1964). The cellulose walls were stained pink colour, lignified cells and protein bodies as blue and suberin as dark green $e t c$. Safranin and fast green were also used wherever necessary.

The temporary preparations were mounted in glycerin and observed under microscopy. Nikon labphoto 2 microscopic unit was used to take photographs of different magnifications. Anatomical features were described as given in the standard Anatomy books (Esau, 1964).

\section{Isolation of endophytes}

The fresh and healthy leaves of plant were processed in laboratory after collection. The collected leaves were surface sterilized and cut it into small pieces of $1 \mathrm{~cm}$ which was placed on the Potato Dextrose Agar medium for isolation of endophytic fungi. Streptomycin was added to the medium to suppress bacterial contamination. The cultures were incubated for 3 weeks at $28^{\circ} \mathrm{C}$ in laboratory condition. After incubation period, colonies were isolated, subcultured and identified.

\section{Molecular characterization}

Fungal DNA was isolated using the NucleoSpin ${ }^{\circledR}$ Plant II Kit (Macherey-Nagel). Primers ITS-1F (TCCGTAGGTGAACCTGCGG) and ITS-4R (TCCTCCGCTTATTGATATGC) were used to amplify the fungal DNA. The quality of DNA was checked using agarose gel electrophoresis. The PCR mixture (20 $\mu 1$ total volume) contained $10.8 \mu$ l Milli Q water, $2 \mu 1$ each of dNTP mix, Taq buffer and both the forward and reverse primers, $1 \mu \mathrm{DNA}$ template and $0.2 \mu 1$ of Taq DNA Polymerase. Thirty five cycles were run each with denaturation step at $94^{\circ} \mathrm{C}$, annealing at $50^{\circ} \mathrm{C}$ and extension step at $72^{\circ} \mathrm{C}$. After $35^{\text {th }}$ cycle, Final extension@ $72^{\circ} \mathrm{C}$ for 7 minutes was carried out. The PCR products were electrophoresed in agarose gel and sequenced in applied biosystems 3500 genetic analyzer and the sequences were submitted to GenBank. The sequences were compared using the NCBI BLAST program. Phylogenetic relationship was established by the neighbor joining method in MEGA software. 


\section{RESULTS AND DISCUSSION}

The leaf sections showed the presence of endophytic fungi. In cross sectional view the leaf exhibits thick midrib and thin smooth lamina. The midrib has a wide semicircular abaxial arc, vascular strand and somewhat smaller adaxial flat segment of vascular strand (Figure $1.1 \& 2$ ). The ground tissue of the abaxial midrib has a thin arc of fungal invested region. This region is thin and darkly stained. Some of the ground cells of the abaxial midrib also possess fungal mycelium (Figure 1.2). There is no fungal mycelium in the phloem cells or xylem cells (Figure. 2).

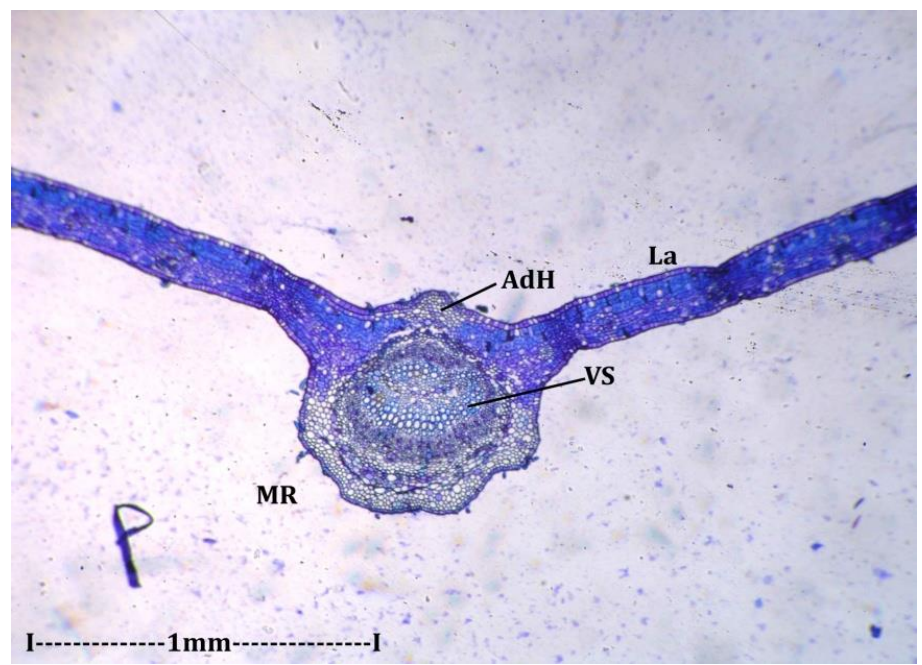

Figure 1.1 T.S of leaf through midrib

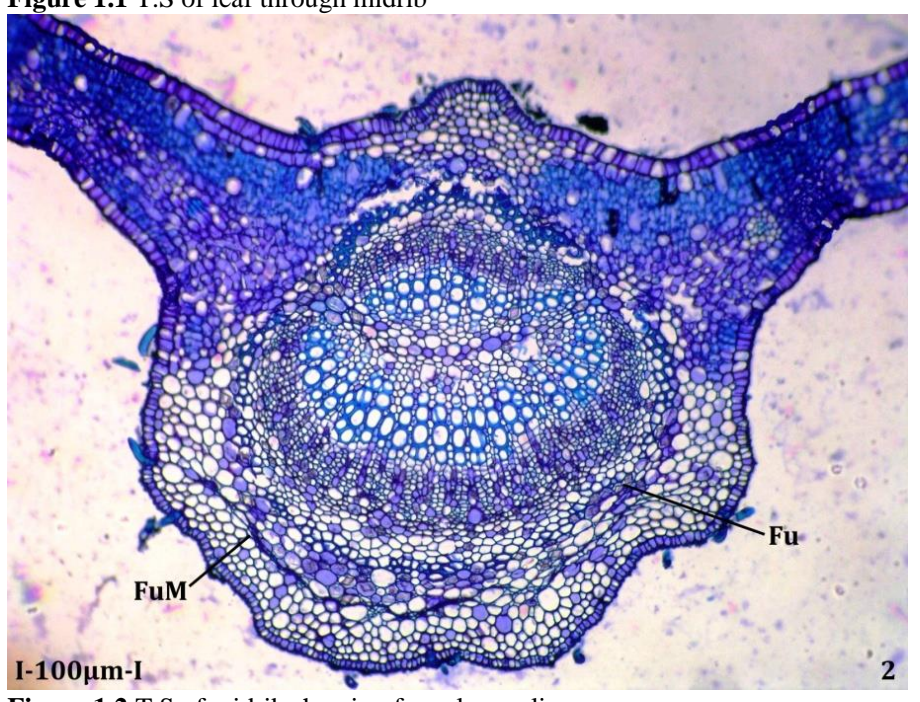

Figure 1.2 T.S of midrib showing fungal mycelium

Legends : AdH - Adaxial Humb, FuM - Fungal mycelium, La - Lamina, MR

- Midrib, VS - Vascular strand

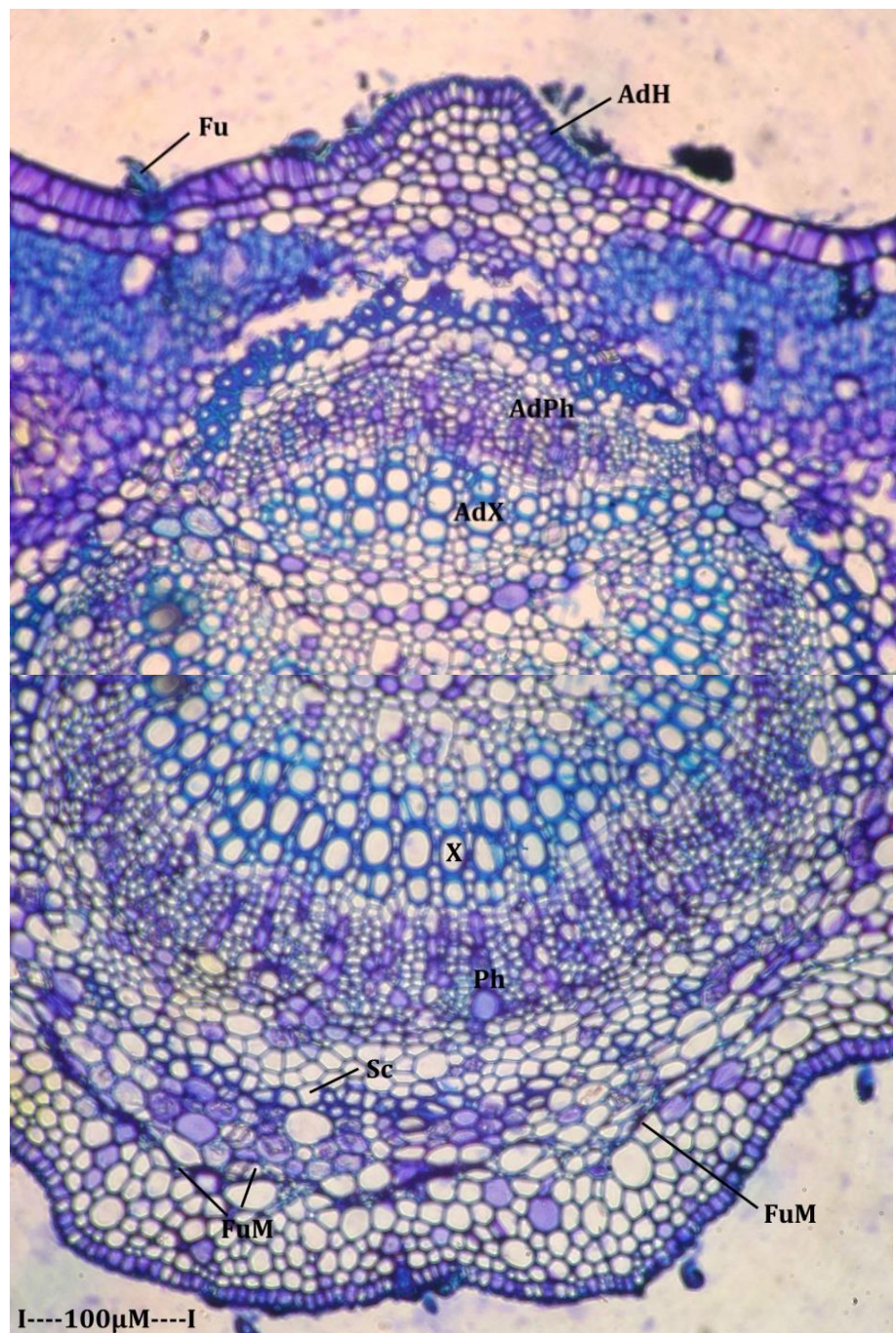

Figure 2 T.S of leaf midrib - enlarged

Legends : AdH - Adaxial Humb, AdPh - Adaxial Phloem, AdX - Adaxial Xylem, FuM - Fungal mycelium, $\mathrm{Ph}-\mathrm{Phloem} \mathrm{Sc}-$ Sclerenchyma, $\mathrm{X}$ Xylem

Around the wide circular, vessel elements of adaxial segment of xylem, there are dark, thick layers of fungal mycelium. It seems that fungal mycelium has penetrated the xylem zone through the adaxial part of phloem rays (Figure. 3.1) In the marginal part of the leaf, the fungal mycelium is seen on the surface of the epidermal cells. The mycelium has not yet penetrated the mesophyll tissue (Figure. 3.2).

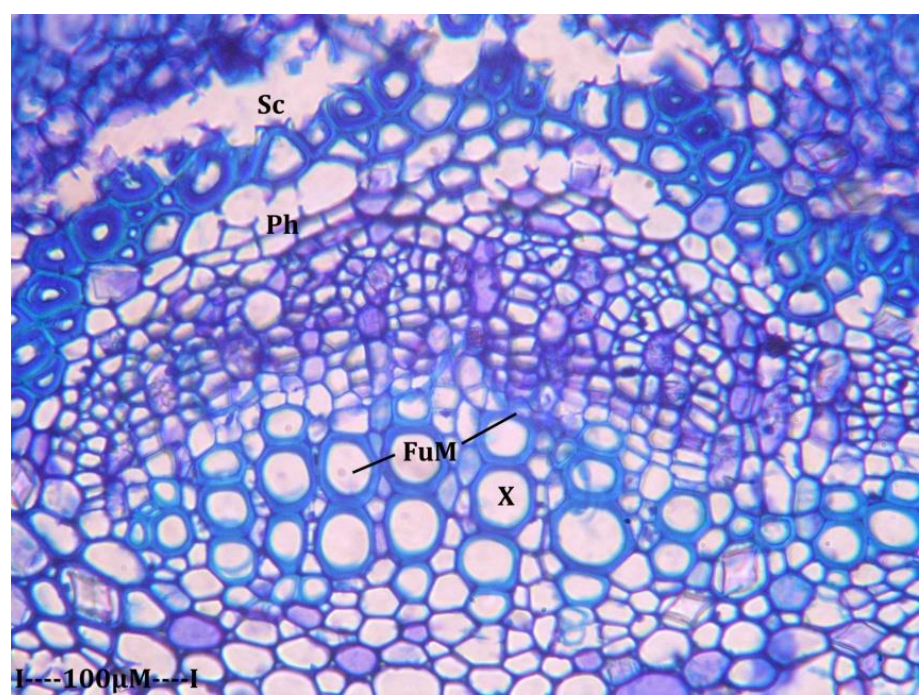

Figure 3.1 T.S of Midrib Abaxial vascular segment enlarged 


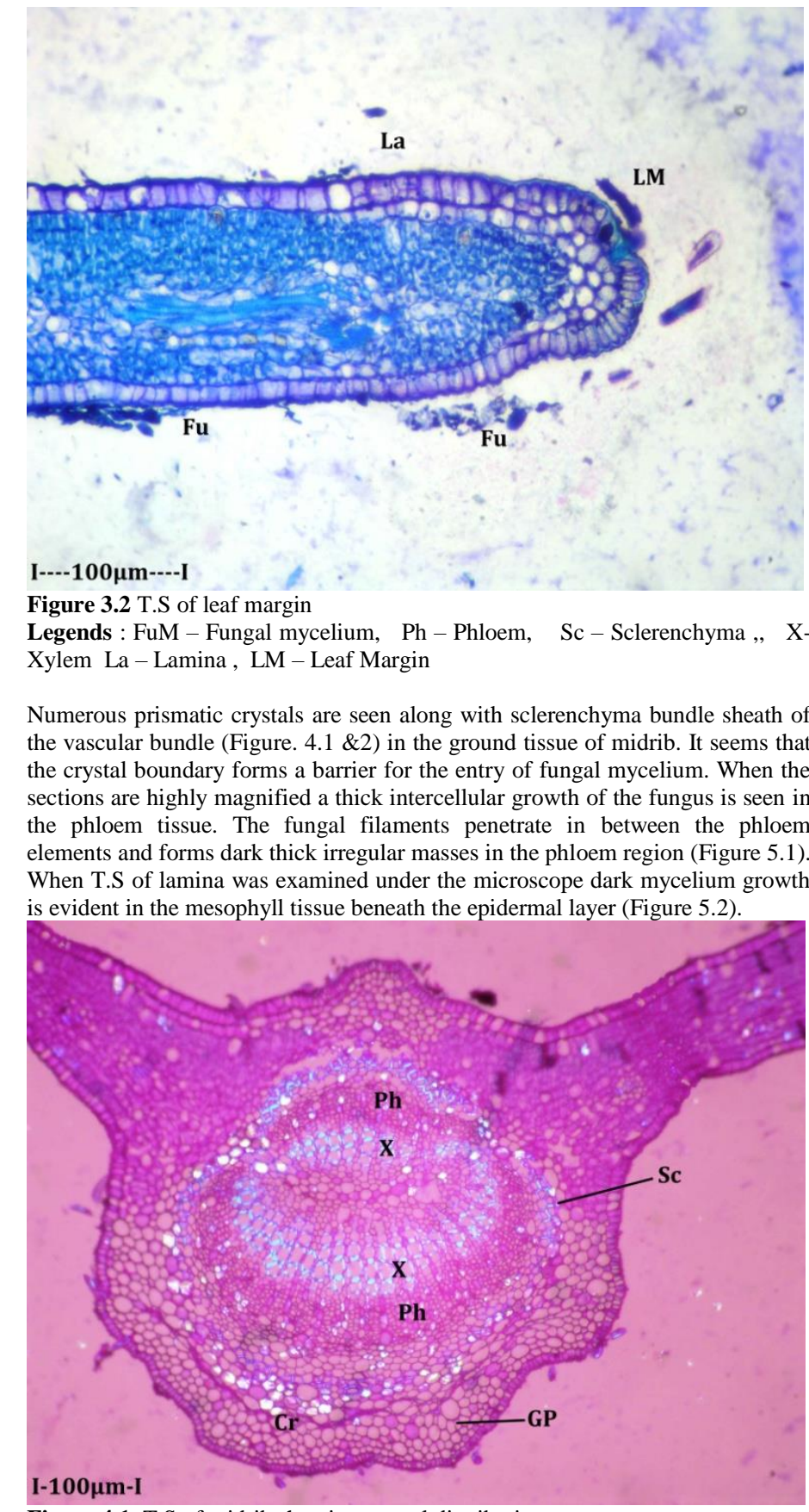

Figure 4.1 T.S of midrib showing crystal distribution

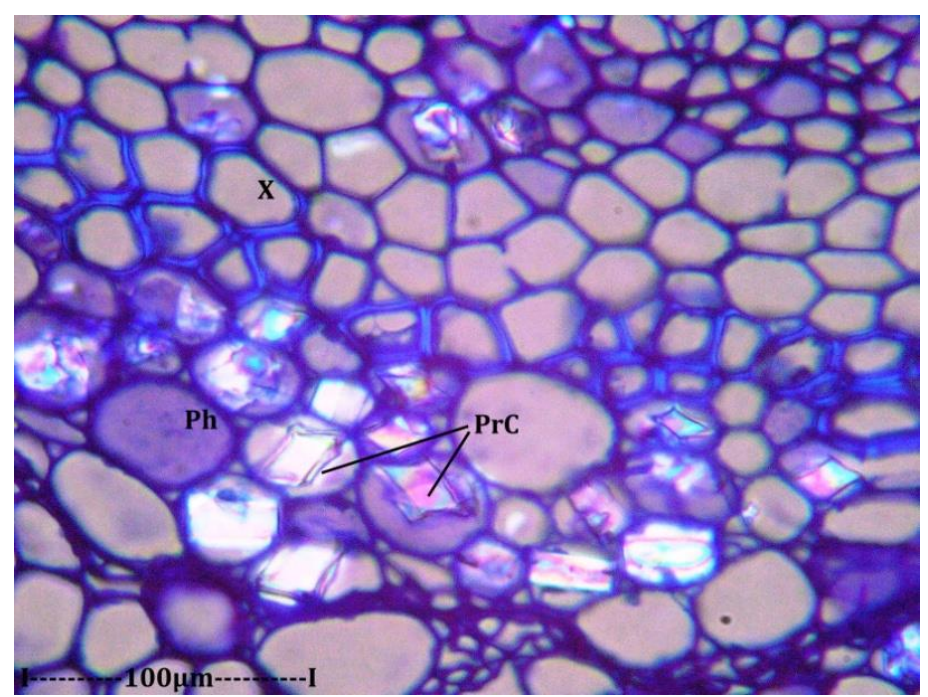

Figure 4.2 Prismatic crystal in phloem parenchyma

Legends : Cr -Crystal, GP - Ground Parenchyma, PrC - Prismatic Crystal, Ph Phloem, Sc- Sclerenchyma, X- Xylem

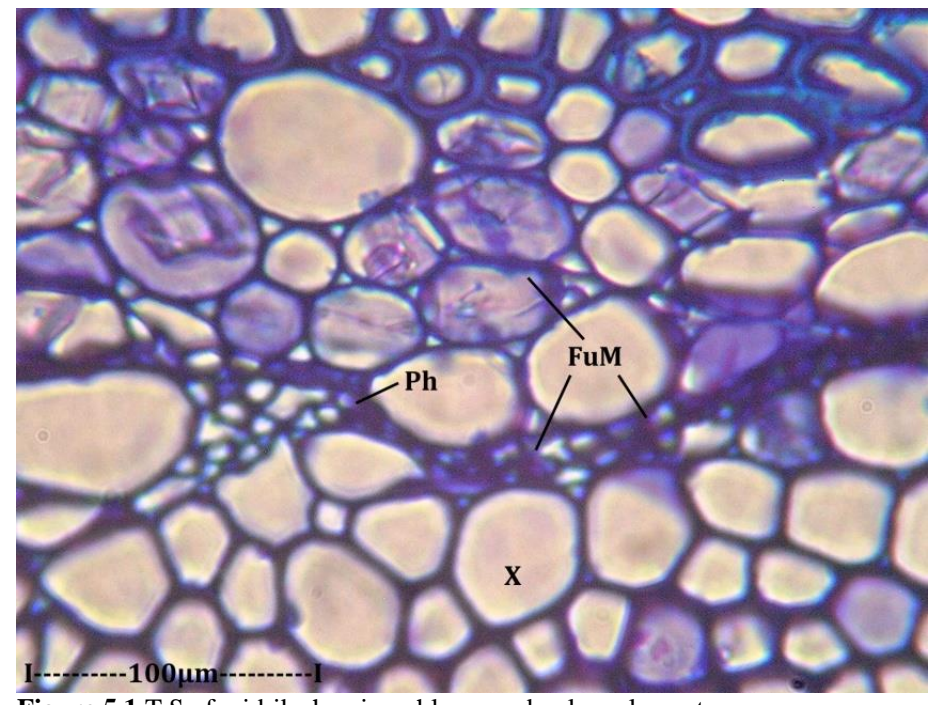

Figure 5.1 T.S of midrib showing phloem and xylem elements

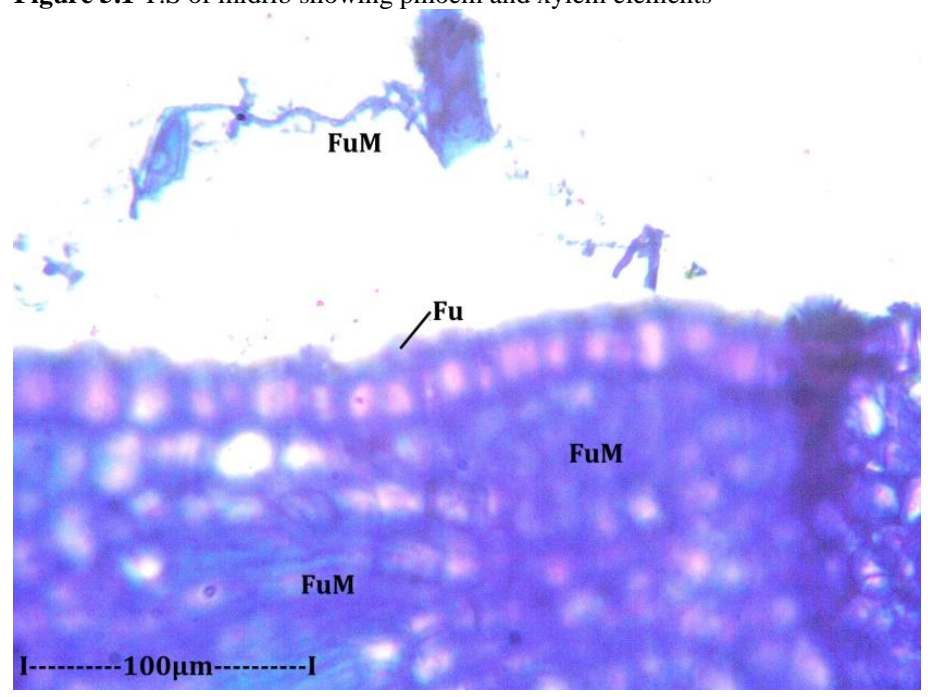

Figure 5.2 A portion of leaf T.S showing epidermal layer with fungal infection

Legends : Fu - Fungus FuM - Fungal mycelium $\mathrm{Ph}-\mathrm{Phloem} \mathrm{X}$ - xylem

In some of the sections, fungal mycelium is seen spreading over the surface of the epidermal cells. They are also seen penetrated into the epidermis, inner cells of the palisade tissue. The mycelium is thin wiry and non-septate (Figure 6.1 \&2)

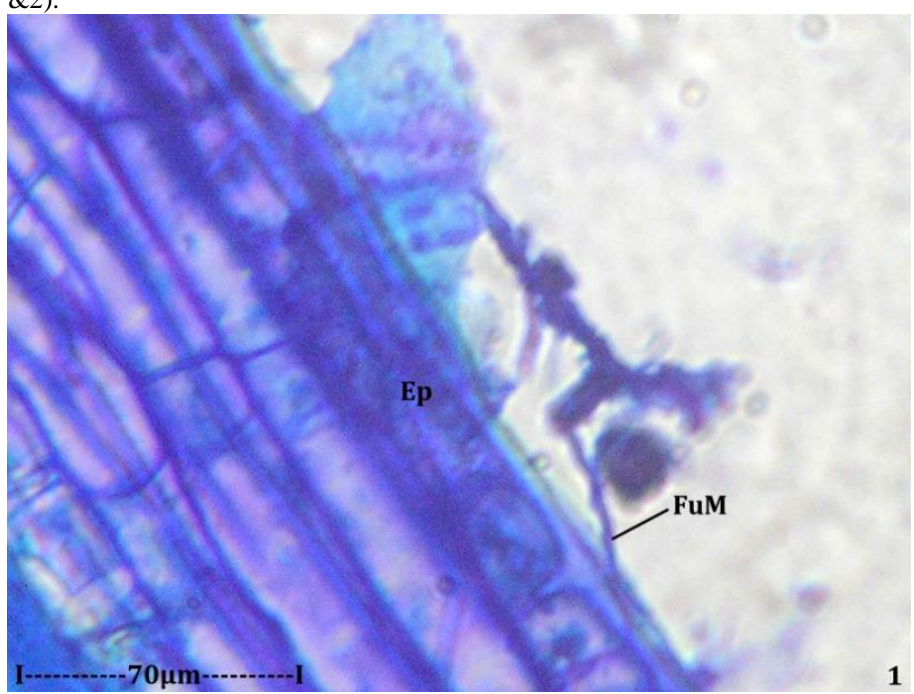

Figure 6.1 T.S of leaf - Epidermal cells showing 


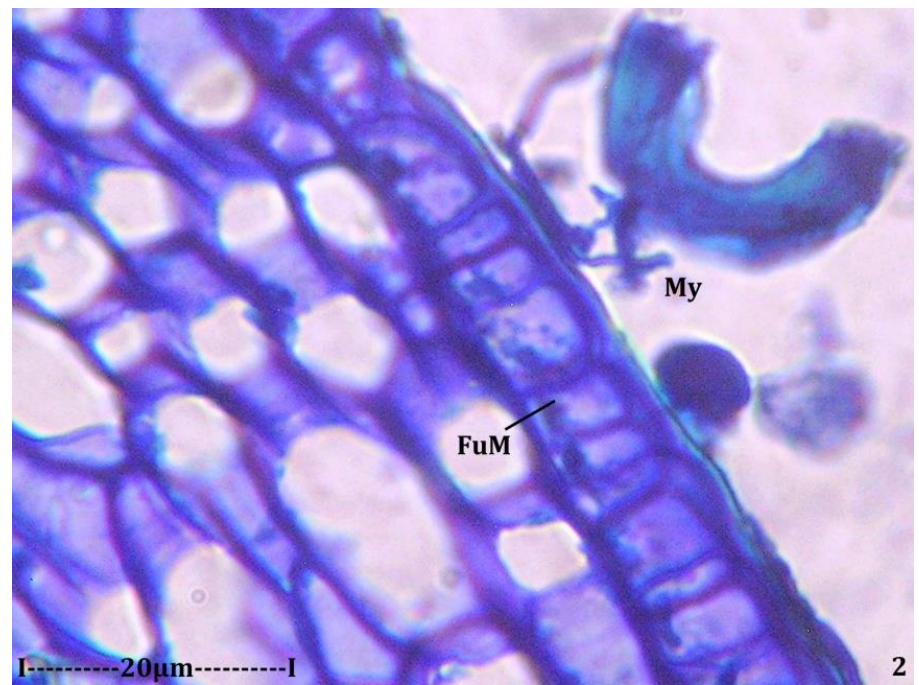

Figure 6.2 Fungus mycelium seen on the epidermis and fungal mycelium penetrating to mesophyll tissues

Legends : Ep - Epidermis FuM - Fungal mycelium

The studies on the localization of endophytic fungi have been reported less. Direct observation studies help us to understand the interaction between the host and its endophyte, mode of infection and the extent of their association. The usage of various stains like lactophenol cotton blue, $\mathrm{LOH}$-aniline blue , Pianese
IIIB Stain etc were also made by different authors to study the anatomical association of endophytic fungi with their hosts. Reyna et al., (2012) detected the endophytic fungus Undifilum oxytropis within the petioles and leaves of Oxytropis sericea. Electron microscopy and confocal microscopy were employed to detect the endophytic fungus inside the tissues. Johnston et al. (2006) employed microscopic techniques and labeled with fluorescent dye that detect the (1/3)-B-D-glucan within fungal cell. Insitu hybridization technique was employed by Pirttilä et al., (2005) to study the distribution of endophytes in scots pine. Endophytic fungi were found to be localized in the stem and leaf tissue of Stevia rebaudiana and was observed with the help of lactophenol cotton blue by Kumari \& Chandra, (2013). Similar results have been reported for the localization of endophytic fungi in the leaf of Catharanthus roseus (Lakra et al., 2013) and Tinospora cordifolia (Mishra Y et al., 2015).

The plant tissues specifically leaves were the repository for the endophytic fungi as per earlier reports. The endophytic fungi were cultured on PDA and after 3 weeks of incubation they were subcultured for pure culture. Molecular identification of all 3 fungi has been successfully carried out for the identification of endophytic fungi. DNA was isolated from fungal mycelium and sequenced with ITS1 and ITS 4 primers. The NCBI BLAST search for similarity revealed the closest match to Aspergillus niger (MT090011), Diaporthe longicolla (MN173138) and Schizophyllum commune (MH857808) respectively. The sequences were submitted in GenBank and provided with accession number (Table 1). Phylogenetic tree were constructed (Figure 7-9). Two of the three isolates belong to Ascomycetes whereas Schizophyllum commune belongs to Basidiomycetes. This corroborates with the findings of earlier researchers who reported the dominance of Ascomycetes over Basidiomycetes in the endophytic fungal community (Porras-Alfaro \& Bayman, 2011; Wehner et al., 2014).

Table 1 Taxonomic affiliation of endophytic fungi isolated from Alangium salviifolium and their GenBank accession numbers

$\begin{array}{lllc}\text { Isolate } & \text { Accession } & \text { The Closet GenBank Taxa } & \text { Similarity \% } \\ \text { Codes } & \text { Numbers } & & 100 \\ \text { EF1 } & \text { MN821058 } & \text { Aspergillus niger (MT090011) } & 99.65 \\ \text { EF2 } & \text { MN765101 } & \text { Diaporthe longicolla (MN173138) } & 99.53 \\ \text { EF4 } & \text { MN821480 } & \text { Schizophyllum commune (MH857808) } & \end{array}$

Legend: EF1 - Aspergillus niger, EF2 - Diaporthe longicolla, EF3 - Schizophyllum commune

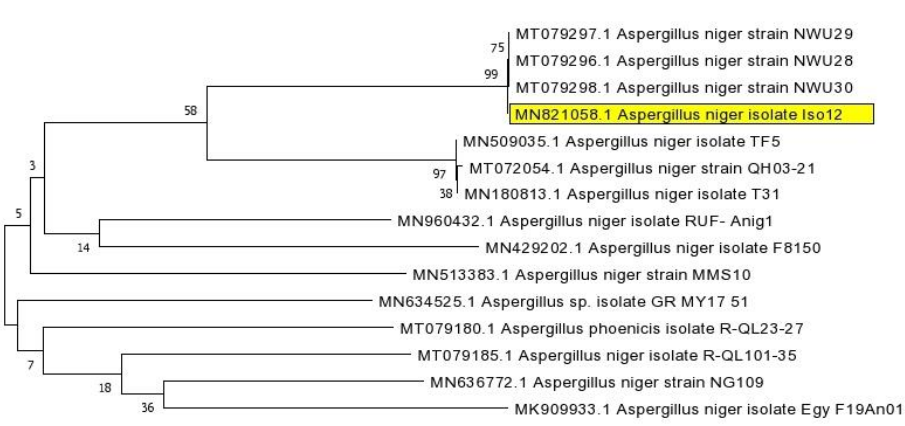

Figure 7 Phylogenentic tree of ITS gene sequences of Aspergillus niger

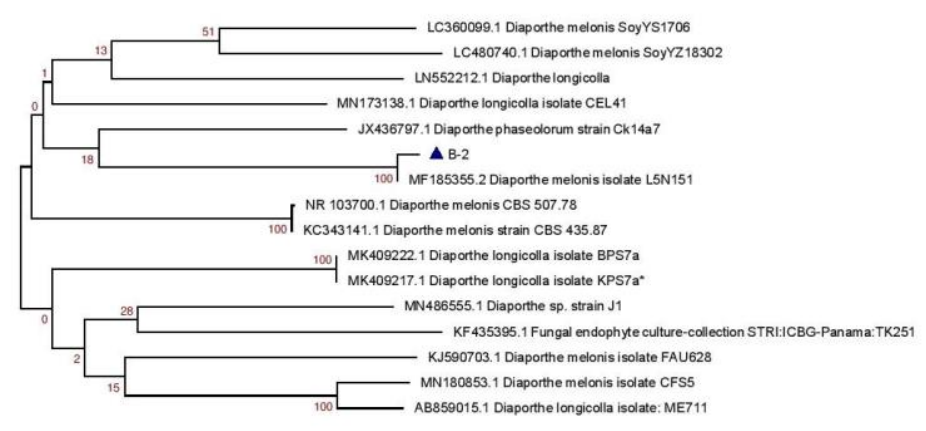

Figure 8 Phylogenentic tree of ITS gene sequences Diaporthe longicolla

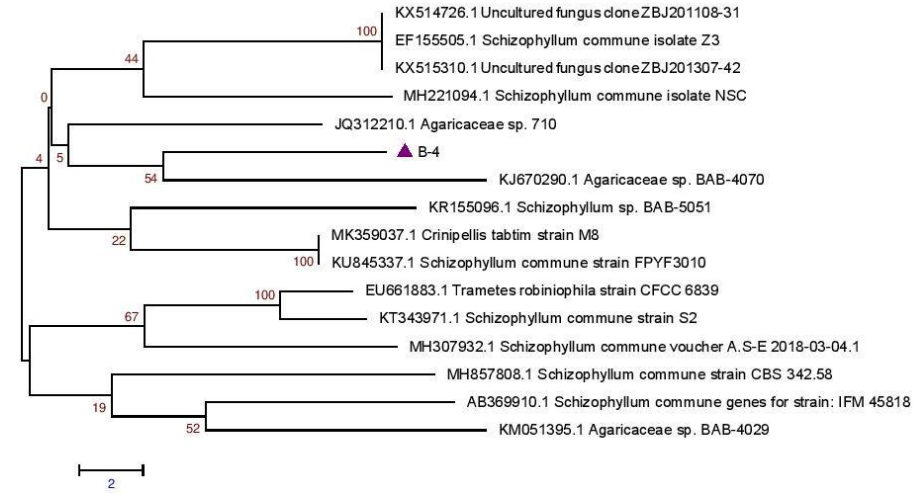

Figure 9 Phylogenentic tree of ITS gene sequences Schizophyllum commune

Many studies were documented for the isolation of endophytic fungi from various medicinal plants since fungal endophytes are known to possess novel secondary metabolites that have pharmaceutical value. The endophytes isolated from this study have been reported in several other studies from various plants. Aspergillus niger is one of the commonly reported endophyte since it is cosmopolitan in nature. Aspergillus niger was isolated as an endophytic fungus from many plants such as Withania somnifera, Cannabis sativa, Achilea millefolium etc.,(Tenguria \& Khan, 2015, Lubna et al., 2018, Satari AH et al., 2018). Although Diaporthe sps. are mostly saprobe or pathogen, reports were also available for the isolation of those as endophytes(Alberto et al, 2016 Agusta et al in 2006). Secondary metabolites of the endophytic fungus Diaporthe longicolla isolated from Pogostemon cablin were reported to possess invitro cytotoxic effects( Wang et al., 2016). Schizophyllum commune has been reported as an endophyte by Gorky \& Jenifer (2016) from Tectonia grandis,(Orlandelli et al., 2012) from Piper hispidum and many others. (Supaphon et al., 2014) isolated Schizophyllum commune from sea grass Enhalus acoroides and evaluated its antimicrobial activity.

\section{CONCLUSION}

The localization of endophytic fungi associated with Alangium salviifolium was reported for the first time in this study. Endophytes are a promising tool for the development of antibiotic resistant drugs and to protect the plant from 
phytopathogens. Hence further detailed study of these endophytic fungi associated with this plant is currently being undertaken which would give us insight into their various bioactivities.

\section{REFERENCES}

Agusta, A., Ohashi, K., \& Shibuya, H. (2006). Composition of the endophytic filamentous fungi isolated from the tea plant Camellia sinensis. Journal of natural medicines, 60(3), 268-272.https://doi.org/10.1007/s11418-006-0038-2

Ahad, H. A., Padmaja, B. S., Sravanthi, M., Ramyasree, P., \& Kavitha, K. (2012). Phytochemical screening and anti-inflammatory actions of Alangium salviifolium root extract. Natural product research,26(17), 16491653.https://doi.org/10.1080/14786419.2011.589054

Alberto, R. N., Costa, A. T., Polonio, J. C., Santos, M. S., Rhoden, S. A. Azevedo, J. L., \& Pamphile, J. A. (2016). Extracellular enzymatic profiles and taxonomic identification of endophytic fungi isolated from four plant species. Genet Mol $\quad$ Res, 15(4), gmr15049016. http://dx.doi.org/10.4238/gmr15049016

Bayat, F., Mirlohi, A., \& Khodambashi, M. (2009). Effects of endophytic fungi on some drought tolerance mechanisms of tall fescue in a hydroponics culture. Russian Journal of Plant Physiology, 56(4), 510 516.https://doi.org/10.1134/S1021443709040104

Deckert, R. J., Melville, L. H., \& Peterson, R. L. (2001). Structural features of a Lophodermium endophyte during the cryptic life-cycle phase in the foliage of Pinus strobus. Mycological Research, 105(8), 997.https://doi.org/10.1017/S0953756201004373

Esau, K. (1964). Plant anatomy, John Wiley \& Sons. Inc New York, London, Sydney.

Gorky, A., \& Jenifer, S. (2016). Distribution of endophytic Fungi in Tectona grandis Linn. F. EPH-International Journal of Biological \& Pharmaceutical Science (ISSN: 2208-2166), 2(11), 01-07.

Gundel, P. E., Martínez-Ghersa, M. A., Batista, W. B., \& Ghersa, C. M. (2010) Dynamics of Neotyphodium endophyte infection in ageing seed pools: incidence of differential viability loss of endophyte, infected seed and non-infected seed. Annals of Applied Biology, 156(2), 199-209. https://doi.org/10.1111/j.1744 7348.2009.00379.x

Hepcy Kalarani, D., Dinakar, A., \& Senthilkumar, N. (2012). Antidiabetic, analgesic and anti-inflammatory activity of aqueous extracts of stem and leaves of Alangium salvifolium and Pavonia zeylanica. International Journal of Drug Development and Research, 4, 298-306.

Johansen, D. A. (1940). Plant microtechnique. McGraw-Hill Book Company, Inc: London.

Johnston, P. R., Sutherland, P. W., \& Joshee, S. (2006). Visualising endophytic fungi within leaves by detection of $(1 \rightarrow 3)$ - - -d-glucans in fungal cell walls. Mycologist, 20(4), 159-162.https://doi.org/10.1016/j.mycol.2006.10.003

Jubie, S., Jawahar, N., Koshy, R., Gowramma, B., Murugan, V., \& Suresh, B. (2008). Anti-arthritic activity of bark extracts of Alangium salviifolium Wang. Rasayan Journal Chemistry, 1(3), 433-436.

Kumar, R., Pate, D. K., Prasad, S. K., Sairam, K., \& Hemalatha, S. (2011) Antidiabetic activity of alcoholic leaves extract of Alangium lamarckii Thwaites on streptozotocin-nicotinamide induced type 2 diabetic rats. Asian Pacific journal of tropical medicine,4(11), 904-909. https://doi.org/10.1016/S19957645(11)60216-2

Kumari, M., \& Chandra, S. (2013). Localisation and isolation of funga endophytes from healthy tissue of Stevia rebaudiana (Bert.). International Journal of Phytomedicine, 5(4), 435.

Lakra, N. S., Koul, M., Chandra, R., \& Chandra, S. (2013). Histological investigations of healthy tissues of Catharanthus roseus to localize funga endophytes. Int. J. Pharm. Sci. Rev. Res, 20, 205-209.

Lubna, Asaf, S., Hamayun, M., Gul, H., Lee, I. J., \& Hussain, A. (2018). Aspergillus niger CSR3 regulates plant endogenous hormones and secondary metabolites by producing gibberellins and indoleacetic acid. Journal of Plant Interactions, 13(1), 100 -111. https://doi.org/10.1080/17429145.2018.1436199

Lucero, M. E., Unc, A., Cooke, P., Dowd, S., \& Sun, S. (2011). Endophyte microbiome diversity in micropropagated Atriplex canescens and Atriplex torreyi var e17693.https://doi.org/10.1371/journal.pone.0017693

Mishra, Y., Mittal, J., Singh, A., Batra, A., \& Sharma, M. M. (2015). In vivo and in vitro histological localization of endophytic fungi in Tinospora cordifolia (Willd.) Miers ex Hook F. \& Thomas. Journal of applied research on medicinal and aromatic plants, 2(1), 30-33. https://doi.org/10.1016/j.jarmap.2014.12.002 O'Brien, T., Feder, N., \& McCully, M. E. (1964). Polychromatic staining of plant cell walls by toluidine blue O. Protoplasma, 59(2), 368-373. https://doi.org/10.1007/BF01248568

Orlandelli, R. C., Alberto, R. N., Rubin Filho, C. J., \& Pamphile, J. A. (2012). Diversity of endophytic fungal community associated with Piper hispidum (Piperaceae) leaves. Genet Mol Res, 11(2), 1575 1585.http://dx.doi.org/10.4238/2012.May.22.7
Petrini, O. (1991). Fungal endophytes of tree leaves. In Microbial ecology of leaves Springer, New York, NY, (pp. 179-197). https://doi.org/10.1007/978-14612-3168-4 9

Pirttilä, A. M., Pospiech, H., Laukkanen, H., Myllylä, R., \& Hohtola, A. (2005). Seasonal variations in location and population structure of endophytes in buds of Scots 297.https://doi.org/10.1093/treephys/25.3.289

Porras-Alfaro, A., \& Bayman, P. (2011). Hidden fungi, emergent properties: endophytes and microbiomes. Annual review of phytopathology, 49, 291 315.https://doi.org/10.1146/annurev-phyto-080508-081831

Reyna, R., Cooke, P., Grum, D., Cook, D., \& Creamer, R. (2012). Detection and localization of the endophyte Undifilum oxytropis in locoweed tissues. Botany, 90(12), 1229-1236.https://doi.org/10.1139/b2012-092

Sass, J. E. (1940). Elements of Botanical Microtechnique. McGraw Hill Book Co; New York.

Satari, A. H., Zargar, M. I., Shah, W. A., Bansal, R., \& Bhat, M. F. (2018) Isolation, molecular identification, phytochemical screening and in vitro antioxidant activity of endophytic fungi from Achilea millefolium Linn. Journal of Pharmacognosy and Phytochemistry, 7(4), 87-92.

Sreekanth, P., Sudhakara, K., Gouse Basha, G., Murali, K., \& Sanjeeva Kumar, A. (2011). Anti-ulcer effect of Alangium salviifolium ethanolic leaf extract on gastric lesion induced by ethanol in rats. Asian Journal of Pharmaceutical and Clinical Research, 4(2), 112-4

Strobel, G., \& Daisy, B. (2003). Bioprospecting for microbial endophytes and their natural products. Microbiology and molecular biology reviews, 67(4), 491502.10 .

Supaphon, P., Phongpaichit, S., Rukachaisirikul, V., \& Sakayaroj, J. (2014). Diversity and antimicrobial activity of endophytic fungi isolated from the seagrass Enhalus acoroides. Indian Journal of Geo-Marine Sciences . 43(5):785 797.

Tao, G., Liu, Z. Y., Liu, F., Gao, Y. H., \& Cai, L. (2013). Endophytic Colletotrichum species from Bletilla ochracea (Orchidaceae), with descriptions of seven new species. Fungal Diversity, 61(1), 164.https://doi.org/10.1007/s13225-013-0254-5

Tenguria, R. K., \& Khan, F. N. (2015). Biodiversity of endophytic fungi in Withania Somnifera leaves of Panchmarhi biosphere reserve, Madhya Pradesh. Journal of Innovations in Pharmaceuticals and Biological Science, 2(2), 222-228.

Wang, M., Chen, Y. C., Sun, Z. H., Tan, G. H., Li, H. H., Liu, H. X., ... \& Zhang, W. M. (2016). Study on cytotoxic secondary metabolites of endophytic fungus Diaporthe longicolla A616 from Pogostemon cablin. Zhongguo Zhong yao za zhi= Zhongguo Zhongyao Zazhi= China Journal of Chinese Materia Medica, 41(11), 2112-2117.https://doi.org/10.4268/cjcmm20161122

Wang, M., Chen, Y. C., Sun, Z. H., Tan, G. H., Li, H. H., Liu, H. X., ... \& Zhang, W. M. (2016). Study on cytotoxic secondary metabolites of endophytic fungus Diaporthe longicolla A616 from Pogostemon cablin. Zhongguo Zhong yao za zhi= Zhongguo Zhongyao Zazhi= China Journal of Chinese Materia Medica, 41(11), 2112-2117.

Wehner, J., Powell, J. R., Muller, L. A., Caruso, T., Veresoglou, S. D., Hempel, S., \& Rillig, M. C. (2014). Determinants of root-associated fungal communities within Asteraceae in a semi-arid grassland. Journal of Ecology, 102(2), 425 436.https://doi.org/10.1111/1365-2745.12197

Zahan. R., Alam. M., Islam, S., S Chowdhury. N., B Hosain, S., Mosaddik, A., \& Haq, M. E. (2011). Anticancer activity of Alangium salvifolium flower in Ehrlich Ascites carcinoma bearing mice. International Journal of Cancer Research 7(30), 254-262. http://doi.org/10.3923/ijcr.2011.254.262 